\title{
Deans in Canadian Higher Education
}

\author{
ABRAM G. KONRAD*
}

\begin{abstract}
This article presents a profile of deans in Canadian higher education - their background, career patterns, role characteristics, and professional development needs. Data were collected by a questionnaire mailed to all deans and directors in public degree-granting institutions in Canada. Deans were found to be much like their professional colleagues, and they differed little by major faculty and geographical region. Their identification of areas of strength and needs formed the basis for deriving some implications for professional development in the deanship.
\end{abstract}

\section{RÉSUMÉ}

Cet article présente un profil des doyens dans l'enseignement supérieur canadien - leurs antécédents, l'orientation de leurs carrières, les caractéristiques de leur rôle, et leurs besoins en matière de développement professionnel. Les données ont été rassemblées au moyen d'un questionnaire envoyé à tous les doyens et directeurs d'institutions publiques qui décernent des grades au Canada. L'enquête a montré que les doyens étaient en général fort semblables à leurs collègues, et que les différences s'avéraient minimes quelle que soit l'importance de la faculté et sa situation géographique. C'est leur identification des points forts et des besoins qui a servi de base, et a permis d'en dériver des implications diverses concernant le développement professionnel du doyennat.

In their study of the American college presidency, Cohen and March (1974) described academic organization as "organized anarchies" which are characterized by ill-defined goals, unclear technology and fluid participation. A decade earlier, Clark Kerr (1964) made the profound observation that a university is "... a series of individual faculty entrepreneurs held together by a common parking grievance." However it is defined, the academic organization is among the most complex yet devised.

* Centre for the Study of Postsecondary Education, University of Alberta 
Recent developments in higher education have placed the deanship and its role in directing and managing change into sharper focus. Many deans are immersed in academic accountability, and fiscal implications of staff and program decisions loom large in most aspects of decision-making. The significance of the dean's role amidst educational and social change demands a careful examination of the deanship and the means that can be employed to increase its effectiveness in the governance of institutions of higher education.

Over two decades ago, McGrath (1947) described the three fundamental roles of deans as considering the ends and means of education, selecting faculty members, and preparing budgets. Gould (1964), in an extensive study of the deanship in colleges and universities in the United States, reported that respondents ranked the dean's functions as follows: curriculum work, budget, promotions, evaluation of personnel, and committee work. While major domains of responsibility may have remained unchanged over the past decade, the emphases have changed and will continue to change. Among the latest additions to the challenge facing deans are matters such as collective bargaining, academic accountability and management in a steady state.

In 1976 the University Council for Educational Administration co-sponsored a Research Development Seminar on "The Deanship in Schools of Education" at New York University. In the theme address, Jack Culbertson (1976) outlined six domains of inquiry relevant to the deanship in higher education: baseline data about the deanship, deans as individuals, deans as individuals in organizations, schools of education as complex organizations, schools of education as organizations in environments, and organizational change in schools of education.

\section{METHODOLOGY}

The profile presented in this paper was drawn from a study initiated in the fall of 1976 at the University of Alberta. The project was undertaken to gather baseline data about deans in Canadian higher education - their background, career patterns, role characteristics, and professional development needs. ${ }^{1}$ All deans and directors of colleges, faculties, and schools of public degree-granting institutions in Canada were included in the population of this study.

The survey instrument was a modification of one designed by Cyphert and Zimpher $(1976) .^{2}$ In addition to changes designed to fit the Canadian context, adaptations were also made to standardize response categories and to delete items of a more personal nature as well as those related to other survey interests. A French edition of the instrument was developed for the francophone institutions in Quebec and New Brunswick.

Data collection and compilation occurred in the spring of 1977. Questionnaires were mailed to all deans and directors and useable returns were received from 280 (62.5 percent) of the 448 deans in Canadian universities. Table 1 provides a distribution of returns by geographical region and major faculty. ${ }^{3}$ Returns were fairly evenly distributed across geographical regions, but not by major faculty. Only 36.6 percent of the respondents in Engineering, Business and Law returned completed questionnaires; three-fourths or more of the deans in Medical Sciences, Education and "other" faculties responded.

\section{THE FINDINGS}

The primary focus of this paper is to develop a data profile of deans in Canadian higher 
Table 1

Distribution and Percentage of Returns By Region and Faculty

\begin{tabular}{|c|c|c|c|}
\hline Rec!; 1011 & $\begin{array}{c}\text { Number } \\
\text { Distributed }\end{array}$ & $\begin{array}{c}\text { Number } \\
\text { Returned }\end{array}$ & $\begin{array}{r}\text { Percent } \\
\text { Returned }\end{array}$ \\
\hline Western provinces & 120 & 82 & 68.3 \\
\hline Ontario & 173 & 97 & 56.1 \\
\hline Qucbec: & 70 & 47 & 67.1 \\
\hline At lantic provinces & 85 & 54 & 63.5 \\
\hline Total & $\overline{448}$ & 280 & $\overline{62.5}$ \\
\hline \multicolumn{4}{|l|}{ Faculty } \\
\hline Arts and Sclence & 146 & 92 & 63.0 \\
\hline Medical Sciences & 66 & 49 & 74.2 \\
\hline Engintering, Business, Law & 131 & 48 & 36.6 \\
\hline Education & 53 & 43 & 81.1 \\
\hline Other (Graduate, Extension) & 52 & 48 & 92.3 \\
\hline Total & $\overline{448}$ & $\overline{280}$ & 62.5 \\
\hline
\end{tabular}

education. In most instances, data are presented in tabular form by major faculty so that specific comparisons can be drawn within the broader context of the total sample.

\section{Personal Data}

In Table 2 deans are profiled on several personal dimensions. About half of all deans had been in their current position for less than four years. The mean age of deans was $\mathbf{4 6 . 5}$ years, although they ranged in age from less than forty to over sixty years. Most deans were male and married, although this dominance was less marked in the Medical Sciences faculties.

There was some evidence for upward mobility among deans. Almost half of the deans' parents had less than high school education; only 21 percent of the fathers and 7 percent of the mothers held a bachelor's degree or higher. About a third of the respondents reported a rural background.

Most of the respondents were Canadian citizens; indeed, three-fourths had spent their youth in Canada. Fifty-two percent of those who spent their youth outside Canada did so in Great Britain, 28 percent in the United States, and the remainder in other countries.

\section{Professional Background}

Respondents were asked to provide information about their academic preparation, work experience, and some professional activities. All but nine of the deans earned their first university degree prior to 1965 . Master's degrees were held by 83 percent, with seventy percent of them having been received before 1965. Three-fourths of all respondents held doctoral degrees; 63 percent of the doctorates had been earned prior to 1965 . Almost half (44\%) of all deans received their doctorates in the United States; thirty-five percent in Canada; and the remainder in other countries. Only a few deans (18\%) reported any post-doctoral study, and seventy percent of them had engaged in such study before 1965 . 
Table 2

Personal Dimensions in the Deanship By Major Faculties

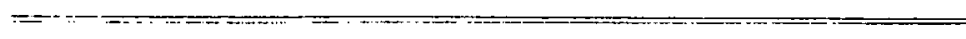

lersell in current position for less than 4 years:

Arts and Science

Medical Sciences

Engineering, Business, Law

Education

Total

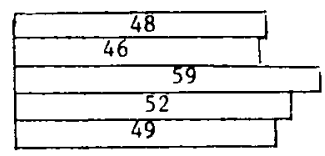

Mean age of respondents:

Years

$\begin{array}{ll}\text { Arts and Science } & 46.3 \\ \text { Medical Sclences } & 48.3 \\ \text { Engineerting, Business, Law } & 46.1 \\ \text { Education } & 45.9 \\ \quad \text { Total } & 46.5\end{array}$

Percent male and percent married:

Male

Married

Arts and Sclence

$96 \quad 87$

Medical Sclences

$63-73$

Engineering, Business, Law

Education

$94 \quad 83$

Tota 1

$\frac{98}{89}$

$\frac{98}{86}$

Percent partint's education

Mother's

Father':

less than high school:

Arts and Sclence

40

Medical Sciences

Engineering, Business, Law

Education

35

$\frac{49}{44}$

49

$\frac{63}{49}$

Total

Percent rural background:

Arts and Science

Medical Sciences

Engineering, Business, Law

Education.

$$
\text { Tota } 1
$$

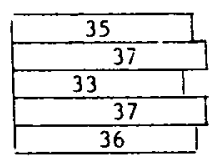

Percent Canadian citizenship and youth in Canada:

\begin{tabular}{c}
$\begin{array}{c}\text { Canadian } \\
\text { Citizenship }\end{array}$ \\
\hline
\end{tabular}

Arts and Science

89

72

Medical Sclences

$90 \quad 80$

Engineering, Business Law

81

80
69

Education

\begin{tabular}{ll}
91 & 77 \\
\hline 88
\end{tabular}

$\frac{91}{88}$

$\frac{77}{73}$




\section{Deans in Canadian Higher Education}

These data indicate that most deans achieved high academic credentials more than a decade prior to this survey.

Of course deans entered their positions with different levels of preparation and experience. Although eleven percent of all deans had been employed in more than five institutions, 75 percent had been employed in fewer than four. Seventy percent of the respondents held the title of dean, 20 percent were directors, while the remainder were chairmen, associate or assistant deans.

Data related to professional background are presented in Table 3. Only in Education faculties did over half (54\%) of the deans report previous training in administration. Of all the respondents, 53 percent had authored a mean of 3 books or monographs; 90 percent had written a mean of 21.3 articles and scholarly papers; and 69 percent were principal authors of a mean of 6.7 research proposals. In each of these activities a large number of respondents were less "active" than the means suggest, however, since the modal responses were one book, two articles and two research proposals.

Most deans ( $88 \%$ ) belonged to professional organizations prior to assuming the deanship -70 percent were national and 30 percent were regional or local in scope. Three categories of responses were developed to report the nature of these organizations: professional, academic and administrative. Memberships were highest in professional $(56 \%)$ and academic (33\%) associations; only ten percent held memberships in administrative associations. Education deans were members of administrative associations more often than were other deans; they also belonged to national associations more often than did their counterparts. Eighty-three percent belonged to two organizations, and 20 percent to three or more. About one-third of the association members had also held an office in that association.

\section{Current Professional Data}

The largest portion of the questionnaire focused upon current role descriptions and preferences of deans. In this section, items related to organizational dimensions, career aspects, personal experiences, and professional development needs are discussed.

Organizational dimensions. Deans work within complex organizations. Some of the dimensions of these organizations are presented in Table 4. Medical Science faculties were within institutions that were largest in mean size, but enrolled fewer students and maintained the lowest student/staff ratio among the faculties.

The organizational structure of faculties varied considerably. About five-eighths of all deans reported directly to a president or vice president. Although three-fourths of the Arts and Science faculties were organized on a departmental basis with a mean of 8.8 departments, less than half of the others had departmental units. Eighty-three percent of the Education deans had professionals on their administrative staffs, while only 63 percent of the Arts and Science faculties reported such appointments. The mean number of staff reporting to the deans of Arts and Science were 23.3 faculty, 4.2 administrative and 5.0 clerical persons.

Appointment terms varied only slightly across faculties. Most deans had term appointments; the mean length of term being 4.9 years. Almost all of the deans were tenured as 

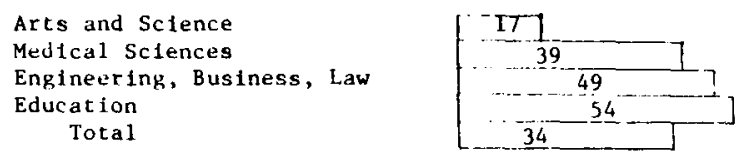

$\begin{array}{lcc}\text { Books } & \text { Articles } & \text { Proposals } \\ 2.6 & 21.2 & 6.4 \\ 2.1 & 25.2 & 6.8 \\ 2.8 & 18.8 & 8.2 \\ \frac{3.7}{3.0} & \frac{16.8}{21.3} & \frac{4.1}{6.7}\end{array}$

\begin{tabular}{ccc} 
Professiona1 & Academ1c & Administrative \\
\cline { 2 - 3 } 58 & -35 & 7 \\
61 & 31 & 9 \\
60 & 27 & 13 \\
$\frac{53}{56}$ & $\frac{28}{33}$ & $\frac{19}{10}$
\end{tabular}

faculty members, although seven percent of the Education deans didn't report faculty tenure. By contrast, 29 percent of Education deans were tenured as a dean compared with only 16 percent in the total sample.

Salary for deans ranged quite widely; about two-thirds of all deans, however, earned more than $\$ 35,000$ per annum. Over one-third of the deans of faculties in the Medical Sciences, Engineering, Business and Law earned $\$ 45,000$ or more per year.

Career Aspects. Table 5 provides information regarding several career aspects of the deanship in Canadian institutions. For 45 percent, the professional challenge of the office was the most important factor in the decision to enter the deanship. Personal development, change, and promotional pressure also were important factors for some, but location and economic benefits were rarely influential. About three-fourths of the Education deans characterized the deanship as one of the most important aspects of life, consuming most of their non-family time. Deans with fewer professionals on their immediate staff, as well as those who were planning to stay in the deanship less than four more years, scored significantly higher on this factor than did their colleagues.

What factors the deans perceived to have had importance in their selection can be compared with their perception of the importance of these factors in functioning in the deanship. Interpersonal skills were rated the highest on a six-point scale, with total mean 
ratings of 4.9 in selection and 5.2 in the execution of duties. (The higher the rating, the greater the importance.) Administrative skills were rated second highest on both dimensions. Scholarship and political acuity were rated third and fourth in selection, but exchanged positions when rated as factors in functioning in the deanship. Among Education deans, both interpersonal skills and scholarship were rated significantly higher in selection by older and more experienced deans than by their colleagues. Older deans also regarded interpersonal skills to have greater importance in functioning in the deanship than did others.

Decision-making processes characteristically were influenced by strong leadership from officials and a broad spectrum of faculty through official structures, as reported by 55 percent of all deans.

Education deans sought professional advice from administrative colleagues or staff members less frequently than did their counterparts. Only 55 percent of Education deans reported that decisions were based primarily on substantive but somewhat political matters.

About three-fifths of all deans described the deanship as satisfying and enjoyable most of the time. Two-thirds were planning to remain in the deanship for less than four more years. Potential candidates for their replacement, according to about 70 percent of the deans in Engineering, Business, Law and Education, would come from an administrative rather than a faculty position or from outside the university. Interestingly, 81 percent of all deans preferred to return to a faculty position upon leaving the deanship, but only 55 percent expected to take such a position. The difference between preference for $(94 \%)$ and expectation of (44\%) taking a faculty position after the deanship was most marked among Education deans. The expectation to assume a faculty position following the deanship appeared quite realistic as only 58 percent of their immediate predecessors took a faculty position upon leaving the deanship. Those who were likely to take a faculty position expressed greater satisfaction in the deanship than did others, as did also those who were planning to stay in the deanship for less than four more years. Fully four-fifths of all deans affirmed their decision to enter the deanship by reporting that they would still become a dean, if they had to do it over again.

Personal Experience. Deans are busy individuals (Table 6). In a typical week, they devoted about ten hours to professional reading, six hours to recreational reading, four hours to physical recreation, and over six hours to other recreational activities. Less than half took all of the previous year's vacation for which they were eligible.

About three-fourths of all deans taught some courses during the previous year. Of the Medical Sciences deans, 51 percent of ficially advised undergraduate students; 39 percent of the Education deans advised master's students; and 19 percent of the Education deans served as major advisor to doctoral students.

About one-half $(54 \%)$ of all deans were currently engaged in research activity. Deans of Engineering, Business and Law faculties reported a much higher degree of research activity (71\%) than did the Medical Sciences deans (31\%). Forty-four percent of all respondents devoted a mean of 15.2 days in paid consulting per year, although Education deans spent only 8.4 days in consulting.

That four-fifths of all deans engaged in less research now than prior to entering the deanship came as no surprise. Similarly, about two-thirds of the deans reported less 
60 Abram G. Konrad

Table 4

Organizational bimensions in the Veanship By Major Faculties

\begin{tabular}{|c|c|c|c|c|}
\hline Size (Means) & $\begin{array}{l}\text { Institutional } \\
\text { Enrollment }\end{array}$ & $\begin{array}{c}\text { Faculty } \\
\text { Enrollment }\end{array}$ & $\begin{array}{l}\text { Faculty } \\
\text { Staff } \\
\end{array}$ & $\begin{array}{r}\text { Student/ } \\
\text { Staff Rat10 } \\
\end{array}$ \\
\hline Arts and Science & 9,477 & 995 & 89 & 12.4 \\
\hline Medicil Sciences & 13,963 & 356 & 61 & 5.9 \\
\hline Engineering, Business, Law & 10,496 & 821 & 47 & 17.6 \\
\hline Education & 9,225 & 997 & 54 & 18.4 \\
\hline Tutal & $\overline{10,333}$ & $\overline{886}$ & $\overline{75}$ & 11.6 \\
\hline
\end{tabular}

Stiucture

Percent deans reporting directly to president or vice president:

Arts and Sclence

Medical Sclences

Engineering, Business, Law Education

Total

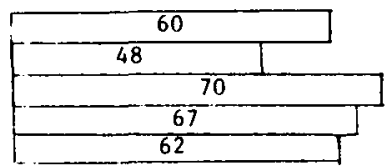

Percent organized by departments with mean number of departments in parentheses:

Arts and Science

Medical Sclences

Engineering, Business, Law (4.9)

Education

(6.2)

Total

$(9.1)$

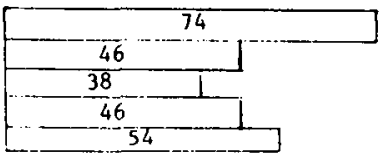

Percent with professionals on administrative staff:
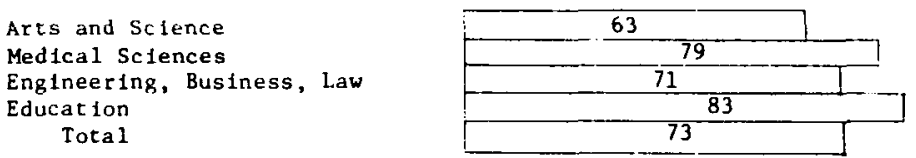

Assistant Administracive Deans Assistants

\begin{tabular}{lll}
1.6 & 1.3 & 1.5 \\
2.4 & 1.8 & 1.9 \\
1.2 & 1.3 & 1.4 \\
1.7 & 2.1 & 1.9 \\
\hline 1.7 & $\frac{1.5}{1.5}$ &
\end{tabular}

Faculty

Administrative Clerical

23.3

4.2

5.0

15.8

4.5

4. 3

4.1

2.8

3.8

$\begin{array}{lll}17.3 & 4.1 & 4.4\end{array}$




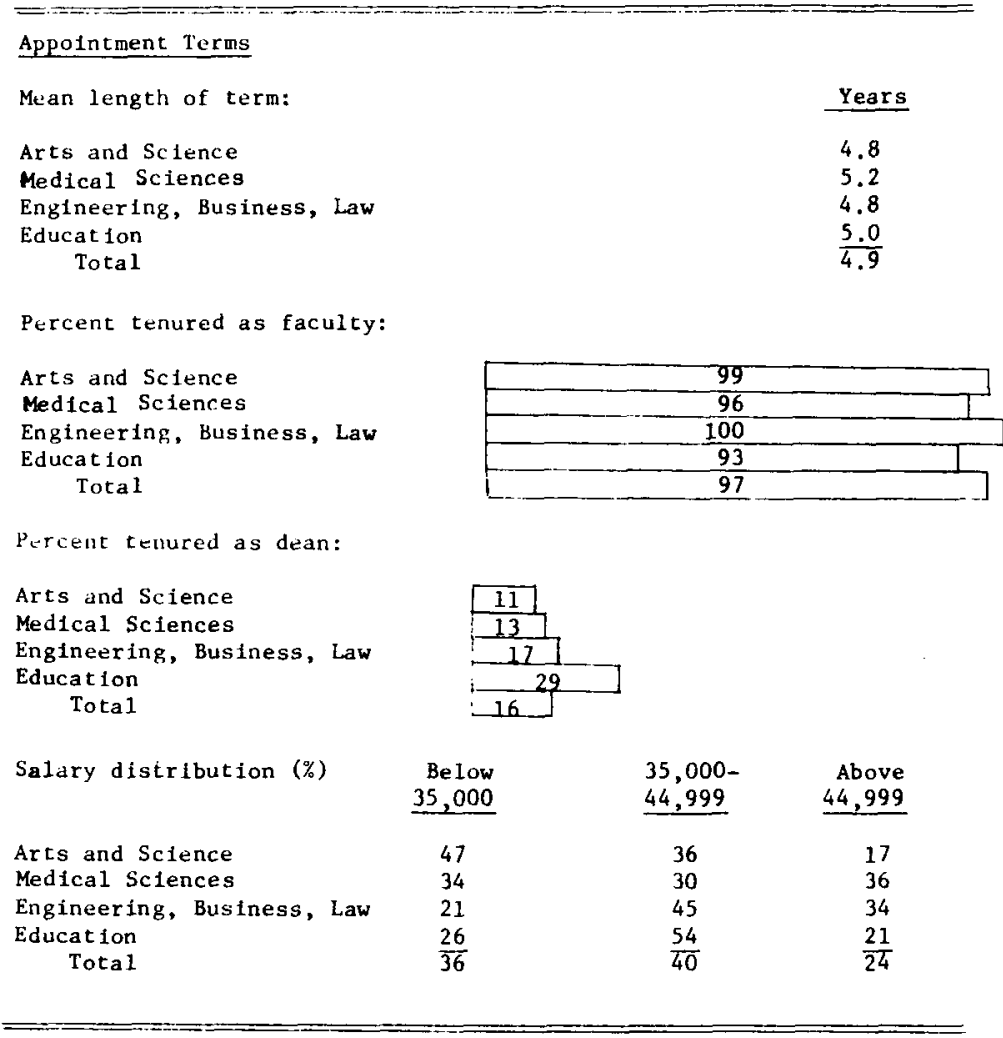

consulting now than earlier; 72 percent received less than $\$ 2000$ during the previous year from consulting, royalties, guest lectures, and honoraria. Nevertheless, 61 deans (22\%) had authored or edited a mean of 2.7 books (mode $=1$ ), and 192 deans $(69 \%)$ had written a mean of six articles (mode $=2$ ) since entering the deanship. A substantially smaller number of deans reported professional writing during the deanship than prior to entering the deanship.

Most deans belonged to professional associations. The distribution of memberships related to the deanship differed considerably from association memberships reported in Table 3. Forty-seven percent of the memberships related to the deanship were in administrative associations like the Canadian Association of Deans of Education. About three out of every ten deans currently held office in an association. Involvement in national associations exceeded involvement in local or provincial organizations.

Professional Development Needs. Respondents identified the major functions of the deanship, activities of greatest success and failure, areas of greatest satisfaction and frustration, area of greatest expertise, area in which previous training might have been helpful, and 
l'ercent insist iufluenced by professional challenge to enter deanship:

Arts and science

Medical Sciences

Engineering, Business, Law

Education

Total

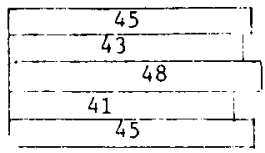

Percent who regard the deanship as one of the most important aspects of life:

Arts and Science

Medical Sciences

Englneering, Business, Law

Education

Total

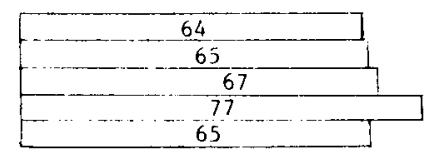

Mean importance of

interpersonal skills:

Selection

Deanship

Arts and Science

Medical Sclences

Engineering, Business, Law

Education.

Total

\begin{tabular}{l}
5.0 \\
5.0 \\
4.6 \\
5.0 \\
\hline 4.9
\end{tabular}

5.3

5.3

5.1

$\frac{5.1}{5.2}$

Mean importance of

administrative skills:

Selection

Deanship

Arts and Science

Medical Sciences

Engineering, Business, Law

Education

Total

$$
\begin{aligned}
& 4.4 \\
& 4.4 \\
& 4.1 \\
& 4.6 \\
& \hline 4.4
\end{aligned}
$$

4.9

5.0

4.8

$\frac{5.1}{4.9}$

Moan tmpictance of scholarship:

Sulection

Iieanship

Arts and Science

3.8

3.6

Medical Sciences

4.4

4.2

Engineering, Business. Law

4.0

4.0

3.2

Education

Total

$\frac{4 \cdot 0}{4.0}$

$\frac{3.6}{3.5}$

Mean importance of

political acuity:

Selection

Deanship

Arts and Scienct

3.8

4.5

Medical Sciences

3.7

4.5

3. 3

3.7

4.5

Education

$\frac{4.8}{4.5}$ 
Table 5 (continued)

Percent who characterize the decision-making process in their unt as influenced by strong leadership from officials and a broad spectrum of faculty through comsittees, faculty senate, etc.:

Arts and Sclence

Medical Sciences

Engineering, Business, Law

Education

Total

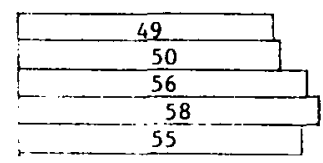

Percent who t: 1 ir.ally seek professional advice from an administrative colleague ir staff:

Arts and Siritilet

Medical Scilwes

Eagineerin:, Lis iness, Law

Education

Tota 1

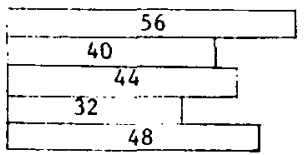

Persent who regard decisions as primarily substantive but somewhat political:

Arts and Silence

Medical Sciunces

Engineering, Business, Law

Education

Tota 1

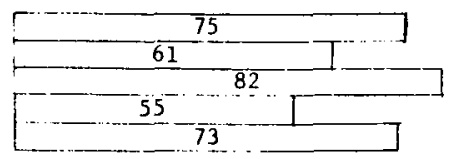

Percent who describe the deanship as satisfying and enjoyable most of the time:

Arts and Science

Medical Sciences

Engineering, Business, Law

Education Total

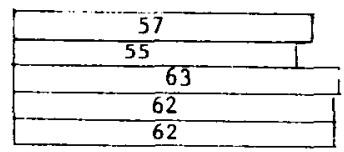

Percent planning to remaln in deanship for less than 4 more years:

Arts and Science

Medical Sclences

Engineering, Business, Law

Education

Total

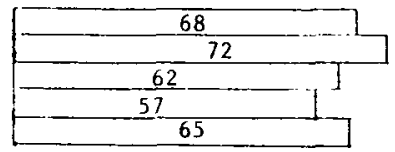

Percent who think a potential candidate for their replacement would come from an administrative position:

Arts and Science

Medical Sciences

Engineering, Busluess, Law Education

$$
\text { Total }
$$

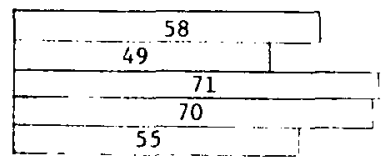




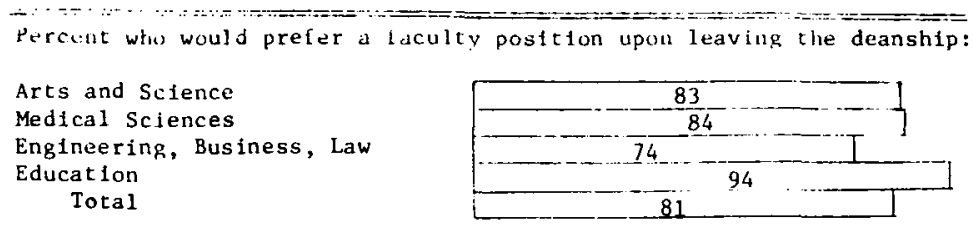

Percent who would likely take a faculty position upon leaving the deanship:
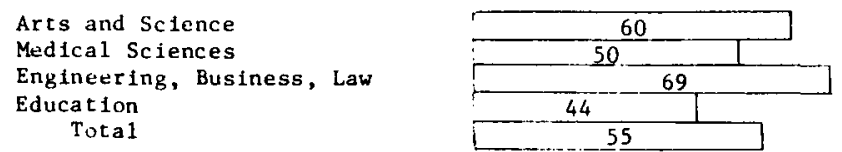

Percent of 1mmedlate predecessors who took a faculty position upon leaving the deanship:
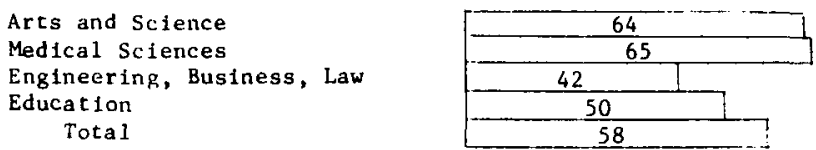

Percent who would still become a dean if they had to do it over again:

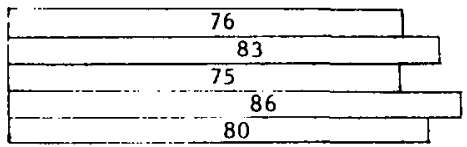

activities that would be pursued if time were miraculously available. A broad classification scheme was derived that could be used repeatedly with these open-ended responses. Factors related to professional development are presented in Table 7.

The perceptions of the deanship varied somewhat among the respondents, but a fairly consistent ordering of functions across the faculties emerged. Twenty-four percent of all deans recorded organizing responsibilities as a major function; twenty percent selected responsibilities related to power and leadership activities. In descending order, the other functions were: staff development, planning, external relations, budgeting, program development, student development and other professional duties.

Thirty-five percent of all deans cited program development as one of their most successful activities. Organizing (20\%) and staff development (13\%) were also identified quite frequently as successful activities. The remaining responses were scattered over the other six major areas. A slightly different picture emerged when deans listed their most signifi- 
65 Deans in Canadian Higher Education

Table 6

Personal Experiences in the Deanship

By Major Faculties

\begin{tabular}{|c|c|c|c|c|}
\hline Mean wetkly hours in: & $\begin{array}{c}\text { Professional } \\
\text { Reading } \\
\end{array}$ & $\begin{array}{c}\text { Recreational } \\
\text { Readlng } \\
\end{array}$ & $\begin{array}{c}\text { Physical } \\
\text { Recreation } \\
\end{array}$ & $\begin{array}{c}\text { Other } \\
\text { Recreation } \\
\end{array}$ \\
\hline Arts and Sclence & 9.5 & 5.9 & 3.8 & 6.0 \\
\hline Medical Sclences & 9.3 & 4.7 & 3.3 & 5.9 \\
\hline Engineering, Business, & Law 10.3 & 7.8 & 4.1 & 8.3 \\
\hline Education & 7.5 & 5.0 & 4.2 & 5.5 \\
\hline Total & 9.4 & 5.9 & $\overline{3.9}$ & $\overline{6.6}$ \\
\hline
\end{tabular}

Percent who took all of last year's vacation for which they were eligible:

Arts and Science

Medical Sclences

Engineering, Business, Law

Education

Total

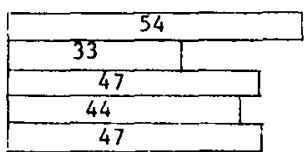

Percent who taught last year:

Arts and Science

Medical Sciences

Engineering, Business, Law

Education

Tata1

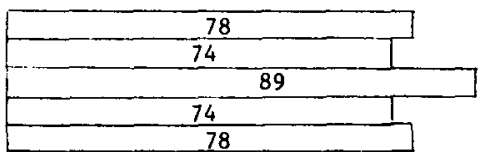

Percent who officially advised undergraduate students:

Arts and Science

Medical Sciences

Engineering, Business, Law

Education

Total

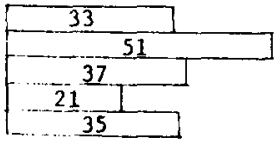

Percent who officially advised master's students:

Arcs and Science

Medical Sciences

Engineering, Buslness, Law

Education

Total

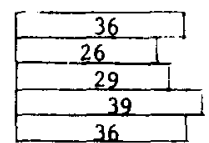

Percent who officlally advised doctoral students:

Arts and Science

Medical Sciences

Engineerning, Business, Law

Education

Total

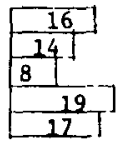

Percent currently engaged in research:

Arts and Sclence

Medical Sclencer

Englneering, Business, Law

Education

Total

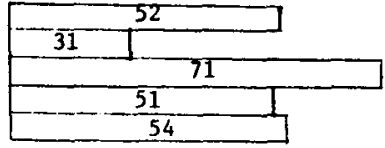


66 Abram G. Konrad

Table 6 (continued)

Percent engaged in consulting with mean days per year in parentheses:

Arts and Sclenci

Medical Sclences

Englneering, Business, Law

Educat1on

Tutal

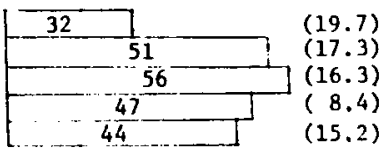

Percent engayed in less research now than prior to assuming the deanship:

\section{Arts and Science \\ Medical Sclences \\ Engineering, Business, Law \\ Education \\ Total}

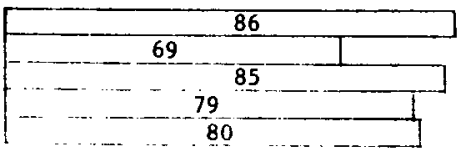

Perceul eligaged iu less cunsulting now than prior to entering the deariship:

Arts and Sclence

Medical Sclences

Engineering, Business, Law

Education

Total

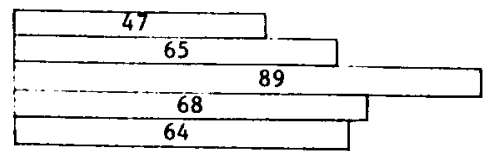

Percent who recelved less than $\$ 2000$ from consulting, honoraria, etc.;

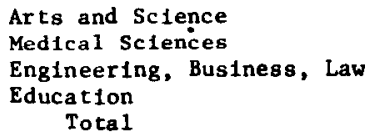

Mean authorship

in deanship:

Arts and Sclence

Medical Sciences

Engineer Ing, Business, Law

Education

Total

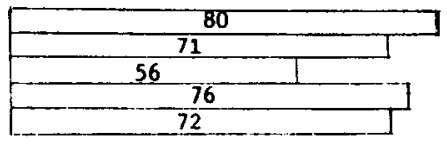

$\underline{\text { Books }}$

Articles

3.3

1.8

7.3

2.4

$\frac{3.5}{2.7}$
6.6

4.9

5.8

Association memberships ( $\%$ : Professional Academic Administrative

Arts and Science

Medical Sciences

25

51

Engineering, Business, Law

Education

Total

$\begin{array}{r}23 \\ 34 \\ \hline 32\end{array}$

$\frac{34}{32}$

21

54

16

68

9
14

$\frac{14}{21}$

$\frac{51}{47}$

Percent who currently hold office in professional organizations:

Arts and Sclence

Med1cal Sciences

Engineering, Bug1ness, Law

Education

Total

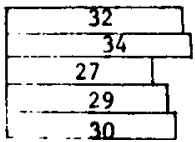


67 Deans in Canadian Higher Education

Table 7

Professtonal Development in the Deanship

By Major Faculty

Major functions of deanship by percentage of response:

\begin{tabular}{llc} 
Arts and Medical & $\begin{array}{l}\text { Engineering, } \\
\text { Sctence }\end{array}$ Sclences & Business, Law \\
\hline
\end{tabular}

Organizing

$22 \quad 28$

Power und leadership 16

Staf $f$ development 15

Planning

15

External relations

Budget ing

Program development

Student development

Professional duttes

28
27
12
4
9
7
8
5
2

24
21
14
7
9
7
6
5
3

$\begin{array}{rr}24 & 24 \\ 18 & 20 \\ 18 & 14 \\ 8 & 10 \\ 12 & 9 \\ 11 & 8 \\ 7 & 8 \\ 5 & 6 \\ 0 & 2\end{array}$

Most successful activities by percentage of response:

Arts and Medical Engineering,

Sclence Sclences Business, Law Education Faculties

$\begin{array}{lrrrrr}\text { Program development } & 26 & 36 & 33 & 36 & 35 \\ \text { Organizing } & 16 & 22 & 18 & 23 & 20 \\ \text { Staff development } & 15 & 9 & 15 & 21 & 13 \\ \text { External relations } & 11 & 9 & 13 & 3 & 8 \\ \text { Planning } & 11 & 7 & 5 & 5 & 7 \\ \text { Budgeting } & 8 & 9 & 13 & 3 & 7 \\ \text { Power and leadership } & 8 & 0 & 3 & 3 & 3 \\ \text { Student development } & 3 & 2 & 0 & 3 & 3 \\ \text { Professional duties } & 3 & 7 & & 5 & 5\end{array}$

Most significant satisfactiuns by percentage of response:

Arts and Medical Engineering,

Sclence Sclences Business, Law Education

A11

Faculties

$\begin{array}{lrrrrr}\text { Power and leadership } & 32 & 19 & 24 & 28 & 26 \\ \text { Organizing } & 14 & 17 & 15 & 14 & 15 \\ \text { Staff development } & 12 & 18 & 11 & 15 & 14 \\ \text { Student development } & 14 & 14 & 16 & 8 & 12 \\ \text { Planning } & 9 & 5 & 8 & 15 & 10 \\ \text { Program development } & 9 & 6 & 2 & 9 & 8 \\ \text { External relations } & 5 & 12 & 3 & 1 & 4 \\ \text { Professional duties } & 4 & 6 & 0 & 2 \\ \text { Budgeting } & 2 & 2 & & 11 & \end{array}$

Ared of expertise in helpling other deans by percentage of response:

Arts and Medical Engineering,

Sclence Sclences Buslness, Law Education

Faculties

Organizing
Power and leadership
Program development
Staff development
Planning
Budgeting
Student development
External relations
Profegsional duties

$\begin{array}{rr}24 & 33 \\ 24 & 9 \\ 8 & 18 \\ 12 & 11 \\ 6 & 11 \\ 7 & 6 \\ 8 & 3 \\ 9 & 5 \\ 2 & 5\end{array}$

$\begin{array}{rr}34 & 30 \\ 13 & 18 \\ 8 & 12 \\ 5 & 6 \\ 16 & 12 \\ 16 & 9 \\ 3 & 9 \\ 0 & 3 \\ 5 & 5\end{array}$

30

16

$9 \begin{array}{rrr}9 & 18 & 16\end{array}$

1213

129

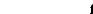

33


68 Abram G. Konrad

Table 7 (cont inued)

\begin{tabular}{|c|c|c|c|c|c|}
\hline & $\begin{array}{l}\text { Arts and } \\
\text { Sclence }\end{array}$ & $\begin{array}{l}\text { Medical } \\
\text { Sclences } \\
\end{array}$ & $\begin{array}{l}\text { Engineering } \\
\text { Business, Law }\end{array}$ & Education & $\begin{array}{c}\text { A11 } \\
\text { Paculties } \\
\end{array}$ \\
\hline Budget ing & 22 & 17 & 33 & 19 & 22 \\
\hline Staff development & 21 & 22 & 18 & 25 & 21 \\
\hline Organtz1ng & 21 & 15 & 3 & 11 & 14 \\
\hline External relations & 10 & 9 & 21 & 8 & 13 \\
\hline Professional duties & 8 & 4 & 8 & 11 & 8 \\
\hline Program development & 2 & 11 & 3 & 14 & 7 \\
\hline Planning & 10 & 4 & 3 & 8 & 6 \\
\hline $\begin{array}{l}\text { Student development } \\
\text { Power and leadersh1p }\end{array}$ & $\begin{array}{l}2 \\
5\end{array}$ & $\begin{array}{r}13 \\
4\end{array}$ & $\begin{array}{l}5 \\
8\end{array}$ & $\begin{array}{l}3 \\
0\end{array}$ & $\begin{array}{l}5 \\
4\end{array}$ \\
\hline
\end{tabular}

Most signiflcant frustrations by percentage of response:

Arts and Medical Englneering,

Sclence Sclences Business, Law Education

Al1

Baculties

$\begin{array}{lrr}\text { Organizing } & 44 & 37 \\ \text { Budgeting } & 20 & 24 \\ \text { Staff development } & 14 & 21 \\ \text { External relations } & 5 & 8 \\ \text { Power and leadership } & 13 & 3 \\ \text { Planning } & 2 & 3 \\ \text { Student development } & 1 & 1 \\ \text { Program development } & 2 & 2 \\ \text { Professional duties } & 0 & 1\end{array}$

37
24
21
8
3
3
1
2
1

33
25
17
10
7
2
3
1
2

$\begin{array}{rr}40 & 41 \\ 15 & 20 \\ 15 & 16 \\ 11 & 8 \\ 14 & 8 \\ 5 & 2 \\ 0 & 2 \\ 1 & 1 \\ 0 & 1\end{array}$

Area in which prior training would have been most helpful by percentage of response:

Arts and Medical Engineering, Science Sciences Business. Law Education

Paculties

Organizing
Budgeting
Power and leadership
Planning
Staff development
Professtonal duties
Program development
External relat lons
Student development

38
33
6
6
11
0
1
5
1

38
24
4
9
3
9
10
3
0

46
20
10
7
7
2
2
2
2

42
23
9
2
5
7
5
5
2

39
25
8
7
6
6
5
4
1

Areas of Immedlate pursuit if time became avallable by percentage of response:

Arts and Medical Engineering, A11 Science Sciences Business, Law Education Faculties

Research
Writing
Reading
Other (travel)
Consultation
Teaching
Program development
Staff development
External relations

$\begin{array}{rrrrr}28 & 29 & 33 & 27 & 29 \\ 24 & 11 & 21 & 23 & 21 \\ 15 & 17 & 13 & 21 & 16 \\ 15 & 10 & 8 & 12 & 13 \\ 5 & 15 & 16 & 5 & 9 \\ 7 & 9 & 6 & 5 & 7 \\ 3 & 5 & 1 & 5 & 3 \\ 1 & 3 & 1 & 0 & 1 \\ 1 & 1 & 1 & 2 & 1\end{array}$


Table 7 (continued)

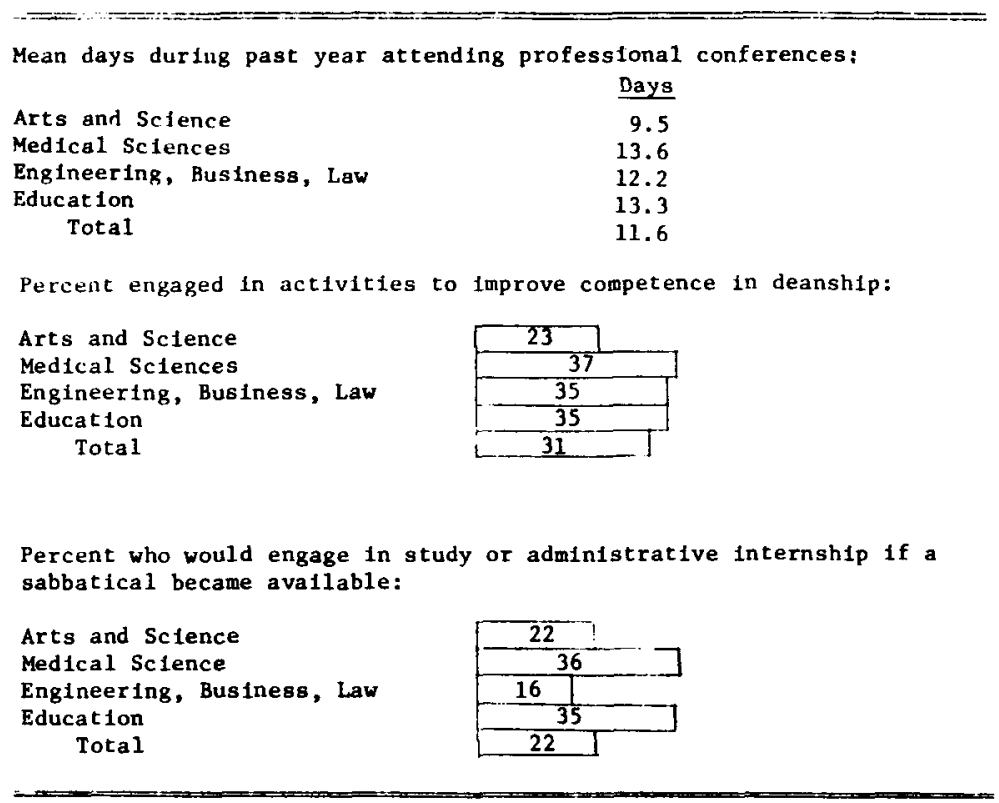

cant satisfactions in the deanship. Activities related to power and leadership brought satisfaction to 26 percent of the deans. Organizing (15\%), staff development (14\%), and student development (12\%) also were each listed by more than ten percent of the respondents. When asked to specify an area of expertise where they might help other deans, respondents again cited organizing (30\%), power and leadership (16\%), and program development (13\%).

Least successful activities and frustrations were also identified. Twenty-two percent reported budgeting activities as a least successful event during the previous year. Staff development $(21 \%)$, organizing (14\%), and external relations (13\%) were also frequently cited. Significant frustrations were experienced by 41 percent in organizing activities, 20 percent in budgeting, and 16 percent in staff development. It almost seemed paradoxical that the areas cited most frequently as failures and frustrations in the deanship were, with the exceptions of budgeting and power and leadership, essentially the same as those cited as successes and satisfactions.

Respondents also were asked about areas of training. Prior training in organizing (39\%), and budgeting $(25 \%)$ would have been helpful to many deans. Both of these areas had also been identified among the least successful and most frustrating activities in the deanship. The responses to how deans would spend an additional eight hours weekly to pursue professional activities was more difficult to interpret. The greatest interests were to pursue research and writing - both activities that could be clearly identified with a professorial role. Indeed, the activities identified seemed quite unrelated to professional needs in the deanship. Whereas deans reported a need for assistance in staff development and external relations, for example, only one percent reported that they would spend newly acquired time in each of these areas. 
Although an average of 11.6 days were spent in professional conferences during the previous year, only 31 percent of the deans engaged in activities designed to improve competence in the deanship. If sabbatical leaves were to become available, only 22 percent of all deans would pursue further study or an administrative internship. The majority of deans would use such time for travel, research or writing.

\section{CONCLUSIONS AND IMPLICATIONS}

The purpose of this paper was to present a descriptive profile of deans in Canadian higher education and to draw some conclusions that might have implications for professional development in the deanship. An intriguing profile of the deanship has emerged.

\section{Conclusions}

1. Canadian deans work in organizations characterized by considerable diversity on a number of descriptive variables. Regardless of the differences by major faculty and geographical region, however, remarkable agreement was observed on the major functions and needs of deans.

2. A typical dean had served for less than four years in his current position. A male of 46.5 years, his parents completed high school and he lived in an urban setting as a Canadian citizen. He received his doctorate prior to 1965 in the United States and had served in fewer than four institutions of higher learning.

3. Deans appeared to be busy persons, pursuing the deanship and also attempting to maintain their professional currency. Although most deans did not take their holiday entitlement, many pursued recreational and professional activities independently and through memberships in national associations and participation in short conferences.

4. It is a myth that decisions in the deanship are primarily based upon substantive matters of an academic nature and arrived at through collegial interaction. Interpersonal and administrative skills, and political acuity rather than scholarship constitute the most important tools of the deanship. In matters that go beyond substantive issues, deans might better be advised to confer with their administrative staff and their counterparts in other faculties than to engage their professional colleagues in "democratic" decisionmaking processes.

5. That most deans were tenured as faculty and not as deans may be indicative of some ambivalence in the deans' "search for identify." Although scholarship was perceived to hold little importance in the deanship, most respondents continued to engage in professorial activities such as writing books and professional articles. Given additional time for professional improvement, deans expressed strong interest in further involvement in research, travel and writing rather than in activities of a skill development nature. Many deans also retained major responsibilities for student advising, thereby reducing the time available for staff development and other "more important" activities. Most deans preferred to resume a faculty position after the deanship, although only about half of their predecessors had actually returned to faculty positions. Term appointments may actually weaken the commitment an incumbent makes in the deanship. 
71 Deans in Canadian Higher Education

6. Deans were obviously happy and perceived themselves as functioning successfully in a number of areas. They were also sensitive about their shortcomings and could readily identify areas where prior training or in-service opportunities could have helped them in their responsibilities.

\section{Implications}

1. Although pre-service training will be pursued by some who aspire to university administration, the majority of deans will have their professional needs met through in-service activities.

2. In-service training could be pursued most readily through workshops and conferences focused upon specific roles or skill areas. There simply isn't much time available for systematic study in the deanship.

3. In the pursuit of professional development activities, deans could benefit from greater interaction across faculties, both at local and regional levels, rather than from meeting primarily at a national level in isolated faculty groupings.

4. There was a high degree of similarity between the needs of some deans and the expertise of others. Deans could become their own best instructors, and could enhance their performance through a stronger identification with the university administration.

5. More research and writing is needed on the deanship in Canadian higher education. Perhaps some of this could best be undertaken by those who have served as deans and who have an interest in the development of materials to increase the effectiveness of the deanship.

In closing, the perspectives on the deanship offered few surprises. Canadian deans are much like their professional colleagues and also similar to their counterparts in the United States. What was similarly reassuring was that deans differed only minimally across major faculties and geographical regions. That many deans have similar strengths and weaknesses, and that training areas can be identified by deans, lends support to the interest in establishing professional development activities. Such activities could help to increase the effectiveness of the deanship in Canadian higher education.

\section{FOOTNOTES}

1 An earlier version of this paper was presented at a Career Development Seminar sponsored by the Ontario Institute for Studies in Education and the University Council for Educational Administration, November 5-8, 1978 in Toronto, Ontario.

2 Doris W. Ryan of the Ontario Institute for Studies in Education provided helpful reactions to the instrumentation, and also collected the data from deans in Ontario.

3 Major faculty groupings included such disciplines as follows: Arts and Science - agriculture, arts, computing sciences, fine arts, forestry, sciences; Engineering, Business, Law - architecture, commerce, engineering, home economics, law, library, public affairs, social work; Education education, physical education, recreational administration; Other - continuing education, graduate study, student services and special sessions. 
72 Abram G. Konrad

\section{REFERENCES}

Cohen, Michael D. and James G. March. Leadership and Ambiguity. New York: McGraw Hill, 1974.

Culbertson, Jack. "Conceptual Framework for the Conference." An unpublished paper for the NYU-UCEA sponsored Research Seminar, New York University, January, 1976.

Cyphert, Frederick R. and Nancy L. Zimpher. "The Education Deanship: Who is the Dean?" An unpublished paper presented at the annual conference of the American Educational Research Association, 1976.

Gould, John Wesley. The Academic Deanship. New York: Teachers College, Columbia University, 1964.

Kerr, Clark. The Uses of the University. Cambridge, Massachusetts: Harvard University Press, 1963.

McGrath, Earl J. "The Office of the Academic Dean." In Norman Burns, ed., The Administration of Higher Institutions under Changing Conditions. Chicago: University of Chicago Press, 1947. 